\title{
An American Studies Program
}

Mass media, commerce and personal exchange are three factors that have contributed to giving the USA an influential position in Sweden after the second World War. There is hardly any correspondence in other countries or regions. In Sweden the consequences of this influence can be studied by behavioural science and humanities. Our chances of learning something about the origin of this influence. about the American milieu, the development of society and culture are, however, fairly limited both at the universities and at the secondary schools. In the present curriculum the role of America has been given little emphasis as compared to the amount of attention to the Roman and British Empires. With regard to this tradition in Swedish education, one might consider it natural that stress has been placed on European problems. Appropriately political and economic development during the sixties has made it desirable to reappraise the contents of teaching in several areas of study.

During the last few years there have been changes according to a new plan of education. Within Languages, Humanities and Political Science, space has been provided for non-European conditions. Of great importance have been Fulbright-lecturers, the Sweden-American Foundation, The American Council of Learned So- cieties, and especially its grant to the University of Uppsala for the establishment of a program in American Literature and American Historv. But these initiatives create the demand for supplementary knowledge - a person who has learnt a little in this field soon realises he does not know enough and wants to learn more. Perhaps it is not so remarkable then that in 1963 both students and teachers greeted with enthusiasm a project that represented both interdisciplinary eduction and research. The thought of starting a new subject, American Studies, was realised at the same time both in Gothenburg and Uppsala. Attempts at co-ordinating the nonscientific studies certainly had been made before. The new aspect of the subject was the aim of making limitations so that it would apply to one single region. What could be looked upon as a fairly radical initiative in Sweden has had a long tradition in the university life of the USA. Subjects like American Institutions or American Civilization have been in an American university curriculum for a long time. The aim was not, however, to plagiarize. Comparable programs in the USA would be these of Scandinavian and North European Studies.

The main motive was to provide in Sweden an intense but mainly critical study of the function of American society and its cultural 
traditions. The subjects was not only to be studied as a part of the B. A. examination but could also be included as a part of studies for technicians and economists.

How could such an enlargement take place without resulting in a superficial knowledge spread over many branches of study? When I concentrate on the Uppsala proposal it is not only due to my personal exyerience of that venture, but also to the fact that this proposal has been discussed by all educational institutions in Sweden. The fairly rigid Swedish betygsystem has made it difficult to introduce such a subject. A modified credit system as used in America would facilitate its achivement. But the student must have an opportunity to become acauainted with a limited number of essential facts and methods.

On the 1-betyg level the student would take five courses. Three of them would be compulsory and would be given more significance than the others: History, Literature and Sociology which when this proposal was first made had progressed furtherest toward fulfillment of the proposal's plan. These subiects would also eive a basic knowledge for the study of Americana in studies close to these disciplines.

There should also be a brief study of city and regional planning. Finally the student should take a course in either Geography or Musicology. It should be emphasized that the problems the student encountered would be connected with those in basic studies. If, for instance, he read about Fredrick
Jackson Turner in History he would deal with economic regions in Geography. If in Sociology he studied racial and cultural minorities, he would read parts of John Hope Franklin's From Slave to Freedom and would have some knowledge of politics, parties and pressure groups or emigration and immigration. When he came across Thoreau, Mark Twain, Hemingway or Steinbeck he would know something about Robber Barons, about sociological interpretations of the American society, or art and life in America.

For the 2-betyg students would concentrate on three of the five subject areas that he studied for 1-betyg. If he wanted to specialize on milieu research he could study Sociology, Architecture and Geography. If he wanted to examine economic or political matters he would choose History, Geography and Sociology, and if he were more interested in aesthetical matters he would choose Literature, Musicology, History or Sociology. Studies for the 2-betyg would deepen this knowledge by further specialization.

For the 3-betyg he would select one of the subiects to examine a more extensive complex of questions. And within that subject he could continue into his licentiate studies. It should be stressed that the choice of subjects in the curriculum was made in consultation with representatives of Economic History and Political Science. And the representatives of Literature consulted those of English Literature. Still the question could be raised whether Philosophy and Ethno- 
graphy should not be represented in the courses.

When this proposal was circulated for comment by the University Chancellor the only notable negative reaction was from the University of Umeå, which maintained that studies in Americana could be provided in existing subjects. In Stockholm, Gothenburg and Lund the practical side caused some worry - was it possible to carry through such a subject within the present curriculum? In other words, should one wait for a modified credit system to be established? In Lund and Gothenburg the question was also raised whether it was suitable to introduce this subject on the licentiate level.

As a result of the comments some changes were made in the curriculum outlined. The 1-betyg studies were begun with a preparatory course in which the teachers of the subject had the opportunity of informing the students in discussion groups. The compulsory parts were to be courses in History and Sociology and the students would then be able to make a choice among the rest of the courses.

The Universitv Chancellor is discussing reforms in training of scholars. He has also decided on a new curriculum which will start in the fall of 1969, and which will proably give better opportunities for studies of this kind.

The Section of American History in Uppsala has become the organizing center for the subject, thanks to a general intensification that has taken place there. Nowadays there is a great demand for knowledge about the USA and our relations with the USA have developed in various areas. All these considerations should lead to a renewed debate on American Studies, a debate in which other authoritities than the Universities should be allowed to state their points of view.

\section{Hdkan Bcrggren}

\section{Fulbright Professor in Uppsala}

The Department of History at Uppsala University has during the spring term had as a visiting Fulbright professor, Dr Norman Risjord, History professor at Wisconsin University, USA. Besides teaching and giving lectures in the more customary way, Dr Risjord has also conducted two courses of American history on the following themes: »From Isolation to Intervention, and "The Response to Industrialization $\gg$. The students who attended these courses have done this as a part of their final examination in History - an experiment which has turned out a great success. During his visit to Sweden Dr Risjord has also been lecturing to students and historical societies at the universities of Lund, Gothenburg, Stockholm and Umeå. 